\title{
Dermoscopy evolution of scurvy: A Disease from the Past with a Technique of the Present
}

\section{Evolución dermatoscópica del escorbuto: una enfermedad del pasado con una técnica del presente}

\author{
Mariana E. Bernardo, Hernán A. Feola, $M^{a}$ Clara Mancinelli y $M^{a}$ Alejandra Verea
}

Department of Dermatology, Hospital San Juan de Dios de La Plata, Argentina

\begin{abstract}
Scurvy is a clinical syndrome due to ascorbic acid deficiency, producing altered collagen synthesis. Scurvy presence with all skin changes is easy for dermatologists to diagnose. However, the presence of a typical appearance of palpable purple as the only clinical finding can be tricky. The diagnosis is clinical and dermoscopy in scurvy lesions has been scarcely published and could contribute to the diagnosis and evaluation of the response to treatment. Here, we present a patient diagnosed with scurvy and the dermoscopy evolution of the follicular purpura before and after treatment.
\end{abstract}

Key words: Dermoscopy. Scurvy. Vitamin C.

\section{Resumen}

El escorbuto es un síndrome clínico debido a la deficiencia de ácido ascórbico, que produce una síntesis alterada de colágeno. La presencia de escorbuto con todos los cambios en la piel es fácil de diagnosticar para los dermatólogos. Sin embargo, la presencia de una apariencia típica de púrpura palpable como único hallazgo clínico puede ser complicada. El diagnóstico es clínico y la dermatoscopia en las lesiones de escorbuto ha sido escasamente publicada y podría contribuir al diagnóstico y evaluación de la respuesta al tratamiento. Presentamos a un paciente diagnosticado de escorbuto y la evolución dermatoscópica de la púrpura folicular antes y después del tratamiento.

Palabras clave: Dermatoscopia. Escorbuto. Vitamina C.

\section{Introduction}

Scurvy is a clinical syndrome due to ascorbic acid deficiency, producing altered collagen synthesis ${ }^{1}$. Scurvy was considered a disease of past times with sporadic cases in risk groups, but currently more cases have been reported due to restrictive eating habits.

The diagnosis is clinical and dermoscopy in scurvy lesions has been scarcely published and could
Disponible en internet: 13-05-2021 Med Cutan Iber Lat Am. 2021;49(1):55-57 www.MedicinaCutanealLA.com
anyer. Este es un artículo open access bajo la por Permanyer. Este es un artículo open access bajo la 
contribute to the diagnosis and evaluation of the response to treatment.

Here, we present a patient diagnosed with scurvy and the dermoscopy evolution of the follicular purpura before and after treatment.

\section{Clinical case}

A 22-year-old male patient with a 10-year history of irritable bowel syndrome and depression, who was hospitalized for a painful left lower limb edema and on physical examination, he presented perifollicular purpuric lesions with hyperkeratosis in the lower limbs (Fig. 1A). He was referring to asthenia, emotional liability, epistaxis, and gingivorrhagia episodes. He had been on a strict diet that excluded fruits and vegetables from the age of 12 due to misinterpretation of a medical indication. The histopathology of a purpuric lesion revealed extravasation of peripheral erythrocytes without vasculitis and the tortuous hair shaft (Fig. 1B). Dermoscopy of the perifollicular purpuric lesions showed corkscrew hair surrounded by hemorrhagic violaceous halo (Fig. 2A). Serum Vitamin $C$ dosing was $0.18 \mathrm{mg} / \mathrm{dL}$ (reference value: $>0.20 \mathrm{mg} / \mathrm{dl}$ ). The diagnosis of scurvy was reached. Vitamin $\mathrm{C}$ treatment was started at $1 \mathrm{~g} /$ day. At the 10-day follow-up, he improved gene- ral manifestations and gingivorrhagia; and dermoscopy of the lesions showed the change from a violet halo to an orange halo, maintaining the morphology of the hair shaft (Fig. 2B). After 45 days, no pathological derma- toscopic findings were evident (Fig. 2C).

\section{Discussion}

Scurvy presence with all skin changes is easy for dermatologists to diagnose. However, the presence of a typical appearance of palpable purple as the only clinical finding can be interesting. Elevated levels of serum Vitamin $C$ do not exclude its diagnosis, because plasma concentrations are normalized by the recent intake of Vitamin $\mathrm{C}^{2}$. Measuring the Vitamin $\mathrm{C}$ level in the buffy coat of the leukocytes is a better estimation of the vitamin body stores. Histopathology serves to rule out other pathologies.

Few publications report the dermoscopy of the perifollicular purpura in the acute stage of scurvy, evidencing the erythrocyte extravasation due to capillary fragility, together with corkscrews hairs due to the formation of disulfide bonds between the hair keratins, which for some authors, it is pathognomonic of scurvy and constitutes an early sign ${ }^{3}$. In chronic scurvy, in the absence

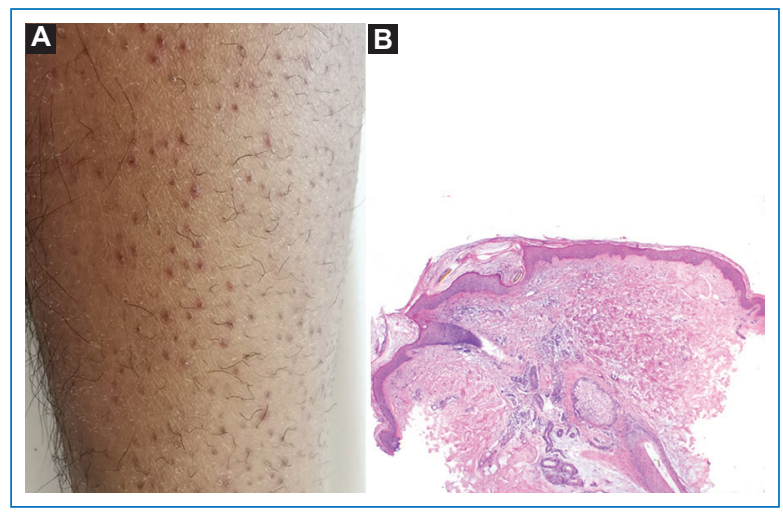

Figure 1. A: perifollicular purpura with corkscrew hairs in lower limbs. B: the histopathological study shows extravagant red blood cells surrounding the hair follicle with no signs of vasculitis. Note the hair shaft cut at different levels inside the follicle $(H-E \times 40)$.

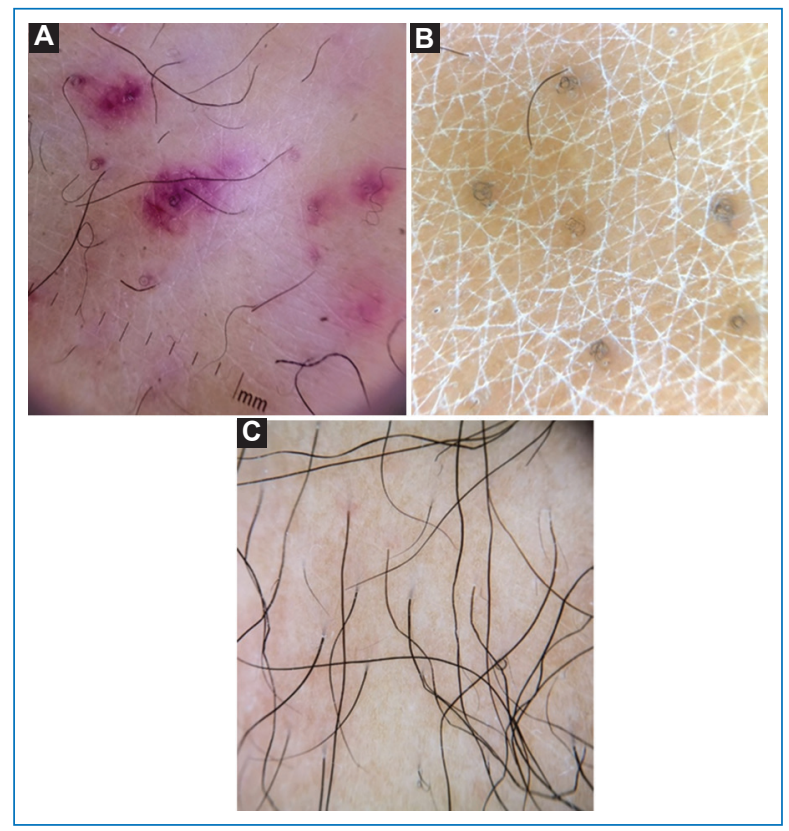

Figure 2. A: at dermoscopy, we find a violet halo surrounding the curly hairs. B: ten days after initiation of the treatment, it is evident to dermoscopy the change of the violet halo to a pale orange halo surrounding the hairs in corkscrews. C: after 45 days, the pale orange halo is not evident and the hairs have their normal morphology.

of treatment, an orange halo has been described surrounding curly hair and on the outside, a violet halo, correlating it with cutaneous fibrosis. The outermost halo corresponds to the laxer dermal collagen that would allow the accumulation of erythrocytes ${ }^{4}$. 
In this case, dermoscopy was performed in the acute stage and 10 days after starting treatment. We hypothesized that the orange halo without the violet halo on the outside in the 10-day follow-up would represent the interruption of erythrocyte extravasation, corresponding only to the hemosiderin deposit, since histopathology did not present fibrosis, being considered a good response to treatment. After 45 days, the dermoscopy did not present pathological findings. The morphology of the hair usually returns to normal after 4 weeks, correlating with normal dermoscopy after 45 days in our patient 5 .

Although the diagnosis could be made from the clinical and dietary history, in cases with only the presence of follicular purpura, dermoscopy would be helpful for diagnosis as well as to evaluate the response to treatment. The first description of the evolution of dermatoscopic findings after treatment is reported.

\section{Conflicts of interest}

The authors declare no conflicts of interest.

\section{Ethical disclosures}

Protection of human and animal subjects. The authors declare that no experiments were performed on humans or animals for this study.

Confidentiality of data. The authors declare that they have followed the protocols of their work center on the publication of patient data.

Right to privacy and informed consent. The authors have obtained the written informed consent of the patients or subjects mentioned in the article. The corresponding author is in possession of this document.

\section{References}

1. Ahangari D, Gillard M, Certad G, Bataille M, Lasek A, Modiano P. Scurvy presenting as pseudo-scleroderma of the leg. JAAD Case Rep. 2019;5:831-3.

2. Monteagudo B, León-Muiños E, Cabanillas M, Suárez-Amor $O$, Álvarez JC. Perifollicular purpura and "corkscrew" hair as manifestations of scurvy. Semergen. 2014:40:407-9.

3. Batalla A, Gutiérrez-González E, de la Mano D. Corkscrew-like hair and perifollicular purpura as a Vitamin C deficiency sign. Med Clin (Barc). 2013;141:e21.

4. Bastida J, Dehesa LA, de la Rosa P. Pale orange perifollicular halo as a dermatoscopic sign in scurvy. Actas Dermosifiliogr. 2008;99:827-8.

5. Olmedo JM, Yiannias JA, Windgassen EB, Gornet MK. Scurvy: a disease almost forgotten. Int J Dermatol. 2006;45:909-13. 